\title{
Quantitative validation of GJC1 promoter hypermethylation in benign and malignant colorectal tumors
}

\author{
Deeqa Ahmed ${ }^{1,2}$, Ragnhild A Lothe ${ }^{1,2}$, Edgar Rivedal, ${ }^{1,2}$ and Guro E Lind ${ }^{1,2}$
}

\author{
${ }^{1}$ Department of Cancer Prevention, Institute for Cancer Research, Oslo University Hospital, The Norwegian Radium Hospital, \\ PO Box 4953 Nydalen, NO-0424 Oslo, Norway \\ ${ }^{2}$ Centre for Cancer Biomedicine, University of Oslo, NO-0316 Oslo, Norway
}

(Correspondence should be addressed to G E Lind at Department of Cancer Prevention, Institute for Cancer Research, Oslo University Hospital; Email: guro.elisabeth.lind@rr-research.no)

\begin{abstract}
We have previously shown that the gap junction protein $\gamma 1$ (GJC1) gene, encoding the connexin45 protein, is inactivated by promoter hypermethylation in colorectal cancer. This was confirmed in a recent Endocrine-Related Cancer publication analyzing a limited number of samples. The aim of this study was to analyze GJC1 in a larger clinical cohort $(n=485)$ and to assess whether or not the promoter hypermethylation was associated with clinical or pathological features. The methylation of GJC1 was confirmed to be tumor specific and was observed in $33 \%$ of colorectal cancers and $12 \%$ of adenomas. The methylation was strongly associated with BRAF mutations $\left(P=5.64 \times 10^{-13}\right)$ as well as with proximal tumor location $\left(P=1.42 \times 10^{-3}\right)$, features compatible with a $\mathrm{CpG}$ island methylator phenotype.
\end{abstract}

Endocrine-Related Cancer (2011) 18 C31-C34

\section{Introduction}

Recently, we investigated the promoter DNA methylation status, assessed by qualitative methylationspecific PCR (MSP), of the connexin gene family members in colorectal cancer (Sirnes et al. 2011). The gap junction protein $\gamma 1$ (GJCl), encoding the connexin-45 protein, was found to be frequently hypermethylated in primary colorectal carcinomas and unmethylated in normal mucosa samples. Furthermore, methylation of GJCl was associated with reduced gene expression, and treatment with the demethylating agent 5-aza-2'deoxycytidine led to re-expression of $G J C l$ in colon cancer cell lines.

\section{GJC1 methylation analysis in a large clinical sample series}

In a recent publication in Endocrine-Related Cancer, Mori et al. (2011) confirmed that GJCl is a potential biomarker for discriminating colorectal cancer patients from controls. The authors used methylated $\mathrm{CpG}$ island amplification coupled with microarray analysis and a well-designed data analysis pipeline to identify 169 candidate loci for cancer-specific hypermethylation. GJCl was among the 14 genes successfully tested with quantitative MSP (qMSP) in a small series of carcinomas $(n=51)$, adenomas $(n=9)$, and normal mucosa $(n=54)$. In that study, the authors pointed out that $G J C l$, as well as the other identified loci, 'merit a large-scale independent validation study' (Mori et al. 2011). In this study, we have used qMSP (forward primer: TATTCGAGCGTTACGTGTCGC; reverse primer: CGCCTACGCACTACGCG; probe: 6FAM-TCGTTTTCGGGTCGCG-MGB) to analyze test and validation sets of malignant and benign tumors as well as normal mucosa samples, counting altogether 485 samples (Tables 1 and 2). The percentile of the highest percent methylated reference $(\mathrm{PMR}=3)$ value across the normal mucosa samples in the test set was used as a fixed threshold for scoring methylation-positive samples in both the test and validation series. Promoter hypermethylation was identified in $12 \%$ of the adenomas, $33 \%$ of the carcinomas, $2 \%$ of the normal mucosa samples taken in distance form the carcinoma, and in none of the normal mucosa 
Table 1 Frequency and distribution of promoter methylation levels (PMR values) sample material measured by quantitative methylation-specific PCR (qMSP)

\begin{tabular}{|c|c|c|c|c|c|c|c|c|c|}
\hline \multirow[b]{2}{*}{ GJC1 } & \multicolumn{2}{|c|}{ Normal mucosa } & \multicolumn{2}{|c|}{$\begin{array}{c}\text { Normal mucosa } \\
\text { from cancer patients }\end{array}$} & \multicolumn{2}{|c|}{ Adenomas } & \multicolumn{2}{|c|}{ Carcinomas } & \multirow[b]{2}{*}{$P$ value $^{\mathrm{a}}$} \\
\hline & $n(\%)$ & $\begin{array}{c}\text { Median } \\
\text { methylated } \\
\text { samples } \\
\text { (IQR) }\end{array}$ & $n(\%)$ & $\begin{array}{c}\text { Median } \\
\text { methylated } \\
\text { samples } \\
\text { (IQR) }\end{array}$ & $n(\%)$ & $\begin{array}{c}\text { Median } \\
\text { methylated } \\
\text { samples } \\
\text { (IQR) }\end{array}$ & $n(\%)$ & $\begin{array}{c}\text { Median } \\
\text { methylated } \\
\text { samples } \\
\text { (IQR) }\end{array}$ & \\
\hline Test set & $0 / 51(0 \%)$ & $-(-)$ & $-(-)$ & $-(-)$ & $7 / 61(11 \%)$ & 14.7 (37.7) & $20 / 64$ (31\%) & $22.3(14.9)$ & $1.9 \times 10^{-4}$ \\
\hline Validation set & $0 / 56(0 \%)$ & $-(-)$ & $2 / 105(2 \%)$ & $7.7(5.4)$ & $6 / 43(14 \%)$ & $13.3(32.9)$ & $35 / 105(33 \%)$ & $31.0(27.2)$ & $2.0 \times 10^{-10}$ \\
\hline $\begin{array}{l}\text { Combined } \\
\text { (test and validation) }\end{array}$ & $0 / 107(0 \%)$ & $-(-)$ & $2 / 105(2 \%)$ & $7.7(5.4)$ & $13 / 104(12 \%)$ & $14.7(36.5)$ & $55 / 169(33 \%)$ & $26.3(22.0)$ & $6.6 \times 10^{-14}$ \\
\hline
\end{tabular}

IQR, interquartile range (75th percentile-25th percentile); $n$, number of positive cases; PMR, percent methylated reference.

Kruskal-Wallis test.

samples obtained from cancer-free individuals (Table 1 and Fig. 1).

In recent years, the $\mathrm{CpG}$ island methylator phenotype (CIMP) has been suggested to be an important pathway in the development of colorectal cancer (Toyota et al. 1999, Weisenberger et al. 2006). CIMP-positive tumors are characterized by concordant hypermethylation in several $\mathrm{CpG}$ loci and include the majority of sporadic colorectal cancers with a microsatellite unstable (MSI) phenotype. Hence, CIMP tumors are associated with many of the features typical of MSI tumors, such as proximal location and $B R A F$ mutation (Weisenberger et al. 2006, Shen et al. 2007) and have also been associated with improved patient prognosis (Ogino et al. 2009). When comparing the promoter methylation status of $G J C l$ with genetic and clinicopathological features, we discovered that GJC1 methylation was more common among MSI $(29 / 45,64 \%)$ primary colorectal carcinomas than among MSS tumors $\left(26 / 124,21 \% ; P=2.44 \times 10^{-7}\right)$. In line with the CIMP concept, the GJC1 promoter methylation was in addition significantly associated with proximal tumor location $\left(P=1.42 \times 10^{-3}\right.$; also reported by Mori et al. (2011)), and the presence of $B R A F$ mutations in exon $15\left(P=5.64 \times 10^{-13}\right)$.
The mean PMR value in cancers from female patients (12.96) was significantly higher than that seen in male patients (7.07; Student's $t$-test, $P=0.026$ ), but no significant difference was seen among normal mucosa samples. In addition, no significant association was seen between DNA methylation and tumor stage or age of the patients.

Receiver operating characteristic (ROC) curves are well suited to determine weather potential biomarkers can discriminate patient samples from normal controls. In concordance with (Mori et al. 2011), we observe an area under the ROC curve (AUC) of 0.67 (95\% confidence interval (CI): $0.61-0.73 ; P=1.6 \times 10^{-6}$ ) for discriminating colorectal carcinomas from normal mucosa samples. Not surprisingly, and probably due to the larger sample series analyzed here (104 adenomas versus nine), the AUC value for discriminating benign tumors from controls was better than previously reported $\left(0.61\right.$. 95\% CI $0.53-0.68 ; P=7.3 \times 10^{-3}$; Table 3). Although somewhat improved, these values are still low, and in a diagnostic setting GJCl would be outperformed by a number of colorectal tumor biomarkers, including VSX2 (AUC 0.93) and the other promising biomarkers identified in the same genome-wide search (Mori et al. 2011). The authors

Table 2 Overview of clinical samples included in this study

\begin{tabular}{|c|c|c|c|c|c|c|c|}
\hline \multirow[b]{2}{*}{ Series } & \multicolumn{2}{|c|}{ Normal mucosa } & \multirow{2}{*}{$\begin{array}{l}\text { Normal mucosa } \\
\quad \text { from cancer } \\
\quad \text { patients } \\
\text { Validation } \\
(n=105)\end{array}$} & \multicolumn{2}{|c|}{ Adenoma } & \multicolumn{2}{|c|}{ Carcinoma } \\
\hline & Test $(n=51)$ & $\begin{array}{l}\text { Validation } \\
(n=56)\end{array}$ & & Test $(n=61)$ & $\begin{array}{l}\text { Validation } \\
(n=43)\end{array}$ & Test $(n=64)$ & $\begin{array}{l}\text { Validation } \\
(n=105)\end{array}$ \\
\hline $\begin{array}{l}\text { Median patient } \\
\text { age (range) }\end{array}$ & $55(22-86)$ & $67(63-72)$ & $71(29-93)$ & $67(62-72)$ & $58(50-64)$ & $71(33-92)$ & $71(29-93)$ \\
\hline $\begin{array}{l}\text { Description } \\
\text { of cohort }\end{array}$ & $\begin{array}{l}\text { Deceased } \\
\text { colorectal } \\
\text { cancer-free } \\
\text { individuals, } \\
\text { collected at the } \\
\text { Institute of } \\
\text { Forensic } \\
\text { Medicine, } \\
\text { University of } \\
\text { Oslo, Norway }\end{array}$ & $\begin{array}{l}\text { Colorectal } \\
\text { adenoma and } \\
\text { carcinoma-free } \\
\text { individuals, } \\
\text { confirmed by } \\
\text { sigmoidoscopy } \\
\text { (Thiis-Evensen } \\
\text { et al. 1999) }\end{array}$ & $\begin{array}{l}\text { Matching the } \\
\text { carcinoma } \\
\text { validation } \\
\text { series }\end{array}$ & $\begin{array}{l}\text { Individuals attending a } \\
\text { population-based } \\
\text { screening study } \\
\text { (Thiis-Evensen } \\
\text { et al. 1999) }\end{array}$ & $\begin{array}{l}\text { Individuals } \\
\text { attending a } \\
\text { second } \\
\text { population- } \\
\text { based } \\
\text { screening } \\
\text { study } \\
\text { (Bretthauer } \\
\text { et al. 2002) }\end{array}$ & $\begin{array}{l}\text { Obtained from a } \\
\text { prospective } \\
\text { series collected } \\
\text { between } 1987 \\
\text { and } 1989 \\
\text { (Meling et al. } \\
\text { 1991) }\end{array}$ & $\begin{array}{l}\text { Derived from a } \\
\text { prospective } \\
\text { series from the } \\
\text { Department of } \\
\text { Surgery at Oslo } \\
\text { University Hos- } \\
\text { pital, Aker } \\
\text { Hospital }\end{array}$ \\
\hline
\end{tabular}

According to National legislation all samples belong to approved research biobanks and approvals are given by the Regional Ethics Committee (S-09282c2009/4958 biobank $2781 ;$ S95151). 


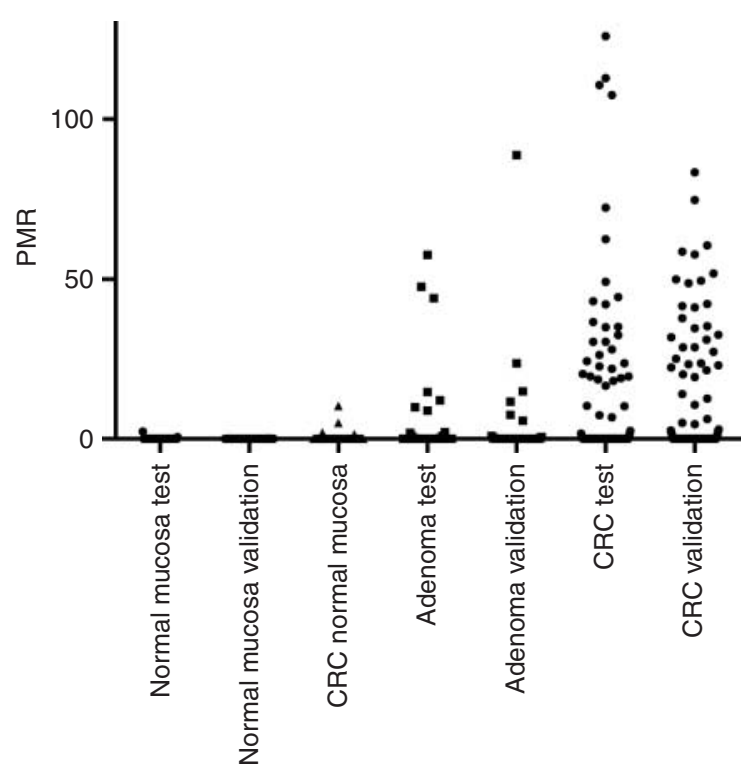

Figure 1 Dot plot of percent methylated reference (PMR) values of GJC1 in test and validation sets of normal mucosa, adenomas, and colorectal cancer. CRC, colorectal cancer.

point out that although the combination of these markers did not improve the diagnostic accuracy compared with VSX2 alone, this might be achieved by including existing colorectal tumor biomarkers. The recently identified SPG2O (AUC 0.95; Lind et al. 2011b) could be an alternative as well as CNRIPI (AUC 0.98) and MAL (AUC 0.96; Lind et al. 2008, 2011a).

\section{Conclusion}

The results by Mori et al. (2011), as well as the quantitative results presented here for a rather large clinical sample series validate our initial findings and pinpoint promoter hypermethylation of GJC1 as a tumor-specific event (Sirnes et al. 2011). In addition to colorectal carcinomas, GJC1 hypermethylation was

Table 3 Receiver operating characteristic (ROC) curve analysis of GJC1

\begin{tabular}{lll}
\hline Samples & AUC $(95 \%$ Cl $)$ & $P$ value \\
\hline CRC $(n=169)$ & $0.67(0.61-0.73)$ & $1.6 \times 10^{-6}$ \\
Stage I and II CRC $(n=101)$ & $0.69(0.62-0.76)$ & $2.0 \times 10^{-6}$ \\
Stage III and IV CRC $(n=68)$ & $0.64(0.55-0.73)$ & $1.5 \times 10^{-3}$ \\
Adenoma $(n=104)$ & $0.61(0.53-0.68)$ & $7.3 \times 10^{-3}$ \\
CRC normal $(n=105)$ & $0.51(0.43-0.59)$ & $7.8 \times 10^{-1}$ \\
\hline
\end{tabular}

ROC curve analysis for the discrimination of tissues from normal mucosa (from colorectal cancer-free individuals). Data are shown for test and validation series combined (lines 1 and 4), and stratified according to tumor stage (lines 2 and 3 ). $\mathrm{AUC}$, area under the curve; $\mathrm{Cl}$, confidence interval; $\mathrm{CRC}$, colorectal cancer. seen among a small subset of adenomas, indicating that the reduction or loss of GJC1 (connexin-45) protein expression can occur early in the colorectal tumorigenesis. Finally, the promoter methylation was restricted to a specific subgroup of colorectal tumors with CIMPlike features, suggesting a role for connexin- 45 in the development of colorectal cancer.

\section{Declaration of interest}

The authors declare that there is no conflict of interest that could be perceived as prejudicing the impartiality of the research reported.

\section{Funding}

This work was supported by grants from the Norwegian Cancer Society (PR-2009-0307, D A; A95068, R A L; PR-2008-0163, G E L).

\section{References}

Bretthauer M, Gondal G, Larsen K, Carlsen E, Eide TJ, Grotmol T, Skovlund E, Tveit KM, Vatn MH \& Hoff G 2002 Design, organization and management of a controlled population screening study for detection of colorectal neoplasia: attendance rates in the NORCCAP Study (Norwegian Colorectal Cancer Prevention). Scandinavian Journal of Gastroenterology 37 568-573. (doi:10.1080/00365520252903125)

Lind GE, Ahlquist T, Kolberg M, Berg M, Eknaes M, Alonso MA, Kallioniemi A, Meling GI, Skotheim RI, Rognum TO et al. 2008 Hypermethylated MAL gene - a silent marker of early colon tumorigenesis. Journal of Translational Medicine 6 13. (doi:10.1186/1479-5876-6-13)

Lind GE, Danielsen SA, Ahlquist T, Merok MA, Andresen K, Skotheim RI, Hektoen M, Rognum TO, Meling GI, Hoff $\mathrm{G}$ et al. 2011a Identification of an epigenetic biomarker panel with high sensitivity and specificity for colorectal cancer and adenomas. Molecular Cancer 10 85. (doi:10. 1186/1476-4598-10-85)

Lind GE, Raiborg C, Danielsen SA, Rognum TO, ThiisEvensen E, Hoff G, Nesbakken A, Stenmark H \& Lothe RA $2011 b$ SPG20, a novel biomarker for early detection of colorectal cancer, encodes a regulator of cytokinesis. Oncogene 30 3967-3978. (doi:10.1038/onc.2011.109)

Meling GI, Lothe RA, Børresen AL, Hauge S, Graue C, Clausen OP \& Rognum TO 1991 Genetic alterations within the retinoblastoma locus in colorectal carcinomas. Relation to DNA ploidy pattern studied by flow cytometric analysis. British Journal of Cancer $\mathbf{6 4}$ 475-480. (doi:10.1038/bjc.1991.334)

Mori Y, Olaru AV, Cheng Y, Agarwal R, Yang J, Luvsanjav D, Yu W, Selaru FM, Hutfless S, Lazarev M et al. 2011 Novel candidate colorectal cancer biomarkers identified by methylation microarray-based scanning. EndocrineRelated Cancer 18 465-478. (doi:10.1530/ERC-11-0083) 
Ogino S, Nosho K, Kirkner GJ, Kawasaki T, Meyerhardt JA, Loda M, Giovannucci EL \& Fuchs CS 2009 CpG island methylator phenotype, microsatellite instability, BRAF mutation and clinical outcome in colon cancer. Gut $\mathbf{5 8}$ 90-96. (doi:10.1136/gut.2008.155473)

Shen L, Toyota M, Kondo Y, Lin E, Zhang L, Guo Y, Hernandez NS, Chen X, Ahmed S, Konishi K et al. 2007 Integrated genetic and epigenetic analysis identifies three different subclasses of colon cancer. PNAS 104 18654-18659. (doi:10.1073/pnas.0704652104)

Sirnes S, Honne H, Ahmed D, Danielsen SA, Rognum TO, Meling GI, Leithe E, Rivedal E, Lothe RA \& Lind GE 2011 DNA methylation analyses of the connexin gene family reveal silencing of GJC1 (connexin45) by promoter hypermethylation in colorectal cancer. Epigenetics 6 602-609. (doi:10.4161/epi.6.5.15237)

Thiis-Evensen E, Hoff GS, Sauar J, Langmark F, Majak BM \& Vatn MH 1999 Population-based surveillance by colonoscopy: effect on the incidence of colorectal cancer.
Telemark Polyp Study I. Scandinavian Journal of Gastroenterology 34 414-420. (doi:10.1080/ 003655299750026443 )

Toyota M, Ahuja N, Ohe-Toyota M, Herman JG, Baylin SB \& Issa JP 1999 CpG island methylator phenotype in colorectal cancer. PNAS 96 8681-8686. (doi:10.1073/ pnas.96.15.8681)

Weisenberger DJ, Siegmund KD, Campan M, Young J, Long TI, Faasse MA, Kang GH, Widschwendter M, Weener D, Buchanan D et al. $2006 \mathrm{CpG}$ island methylator phenotype underlies sporadic microsatellite instability and is tightly associated with BRAF mutation in colorectal cancer. Nature Genetics 38 787-793. (doi:10.1038/ng1834)

Received in final form 19 August 2011

Accepted 23 August 2011

Made available online as an Accepted Preprint 25 August 2011 